\title{
Physicochemical and Techno-Functional Characterization of Native Corn Reintroduced in the Andean Zone of Jujuy, Argentina ${ }^{\dagger}$
}

\author{
María Alejandra Giménez, Cristina Noemí Segundo, Manuel Oscar Lobo \\ and Norma Cristina Sammán * \\ Facultad de Ingeniería, CIITED-CONICET-UNJu, Ítalo Palanca 10, San Salvador de Jujuy 4600, Argentina; \\ malejandragimenez@gmail.com (M.A.G.); segundocristina@gmail.com (C.N.S.); mlobo58@gmail.com (M.O.L.) \\ * Correspondence: normasamman@gmail.com \\ + Presented at the 2nd International Conference of Ia ValSe-Food Network, Lisbon, Portugal, \\ 21-22 October 2019.
}

Published: 5 August 2020

\begin{abstract}
The chemical and techno-functional properties of nine maize races from the Andean zone of Jujuy, Argentina, in the process of reintroduction, were determined. Principal component analysis (PCA) was applied to establish the differences between them. The breeds studied showed high variability in their chemical and techno-functional properties, which would indicate that their applications in the food industry will also be differentiated. The PCA analysis allowed us to group them into four groups, and the Capia Marron and Culli races showed unique properties, mainly in the formation of gels.
\end{abstract}

Keywords: Andean; native corn; physicochemical; race; techno-functional

\section{Introduction}

The native corn of the province of Jujuy, Argentina, has been the foundation of the alimentary culture of the Andean region for centuries. However, the way of feeding has changed with the progression into modernity, and this has led to the loss of numerous maize races, affecting the biodiversity of this crop. Currently, there are very few communities that are suppliers of corn seeds that were cultivated in the past [1]. However, the Puna, Quebrada and Valles regions are considered amongst the most important in situ Andean maize germplasm banks in the country.

The functional properties of corn flours indicate their possible uses in the food industry [2]. For example, the soft endosperm hydrates much better because starches are easily reached by water, as they have fewer bodies of zein surrounding the endosperm [3]. Likewise, the amylose-amylopectin ratio in starches explains the differences in the granular structure, the physico-chemical properties, the swelling power, the viscosity, and the gelatinization temperature, the firmness of the gel, the retrogradation and the susceptibility to enzymatic attack [4]. The incorporation of starches with high amylopectin content into flour has a beneficial effect in bakeries, as higher moisture delays retrogradation and extends shelf life [5]. The same does not occur in pasta, since it produces less firmness and greater stickiness [6]. There are also certain characteristics of the corn that make it suitable for producing specific foods, and for their use in beverages, as they are $85 \%$ grain and $15 \%$ $\operatorname{cob}[7]$.

The re-insertion of native breeds is of great importance for biodiversity, and the knowledge of their technological aptitudes is fundamental in determining their possible industrial applications. The objective of this work was to analyze the nutritional composition and the techno-functional 
properties of the integral flours of nine Andean maize races, and to group them by applying principal components analysis (PCA).

\section{Materials and Methods}

\subsection{Raw Materials, Sowing, Pollination and Harvest}

The genetic material was provided by the INTA-Pergamino germplasm bank. The identification and origin of the genetic material is described in Table 1.

The sowing, pollination and harvesting was carried out in the experimental field of the Research Institute for Family Farming (IPAF INTA, Tilcara, Jujuy, Argentina) for two consecutive years (2017 and 2018). The ear corn were dried in the sun on metal sheets for 7 days (average temperatures: daytime $26^{\circ} \mathrm{C}$ and nighttime $10{ }^{\circ} \mathrm{C}$ ), then they were transported to the laboratory for analysis.

\subsection{Chemical Composition, Amylose Content and Endosperm Hardness}

The macronutrients of the different races were determined by Official Methods of Analysis [8]: humidity at $105{ }^{\circ} \mathrm{C}$ (AOAC 930.15), lipids by acid hydrolysis (AOAC 922.06), total nitrogen and proteins (AOAC 984.13), and ash by carbonization at $550{ }^{\circ} \mathrm{C}$ (AOAC 925.10). The amylose content was determined via the colorimetric method [9]. The hardness of the endosperm was determined by the hectoliter weight technique [3].

\subsection{Properties of Hydration, Absorption of Oil and Thermal}

The water holding capacity (WHC) at $30{ }^{\circ} \mathrm{C}$ and the oil holding capacity $(\mathrm{OHC})$ at $70{ }^{\circ} \mathrm{C}$ were determined by the method of Ahmed et al. (2016). Both properties are expressed as $\mathrm{g} / \mathrm{g}$ flour.

The thermal properties of the flours were analyzed by differential scanning calorimetry (DSC Q2000). The samples were prepared directly in capsules, with a final solids concentration of $25 \%$, and they were heated from 20 to $130^{\circ} \mathrm{C}$ at a rate of $10^{\circ} \mathrm{C} / \mathrm{min}$ in the presence of nitrogen. The initial temperature (To), peak temperature $(\mathrm{Tp})$, final temperature (Tf) and enthalpy $(\Delta \mathrm{H} / \mathrm{g})$ were determined from the area corresponding to each peak.

Table 1. Origin and identification of plant material.

\begin{tabular}{ccccc}
\hline Identifier & Race & Province & Department & Location \\
\hline ARZM 09342 & Capia blanco & Jujuy & Tumbaya & La Ciénaga \\
ARZM 09411 & Capia Garrapata & Jujuy & Tilcara & Huacalera \\
ARZM 09417 & Capia Marrón & Jujuy & Tilcara & Huacalera \\
ARZM 09332 & Cristalino Amarillo & Jujuy & Tumbaya & Huachi Chocana \\
ARZM 09154 & Culli & Jujuy & Tilcara & Potrerillos \\
ARZM 09435 & Cuzco & Jujuy & Tumbaya & Huajra \\
ARZM 09144 & Rojo & Jujuy & Tilcara & Pampa Grande \\
ARZM 09424 & Morocho & Jujuy & Tilcara & Quebrada de la Huerta \\
ARZM 09418 & Perlita & Jujuy & Tilcara & Huacalera \\
\hline
\end{tabular}

\subsection{Firmness of Gels and Stability in Refrigeration}

The gels were prepared from a flour/distilled water dispersion $(3.5 \pm 0.01 \mathrm{~g}$ flour in $25 \pm 0.01 \mathrm{~g}$ water). The dispersion was heated to boiling with constant stirring for 3 min with a consistent heating plate temperature (temperature about $93{ }^{\circ} \mathrm{C}$ ). They were then poured into cylindrical containers ( $3.5 \mathrm{~m}$ internal diameter, $4 \mathrm{~cm}$ high), allowed to stand for $25 \mathrm{~min}$ at room temperature and stored at $4{ }^{\circ} \mathrm{C}$ for $24 \mathrm{~h}$ for stabilization of the gel. The texture analysis was performed at room temperature on a texture analyzer TA.XT plus (Stable Micro Systems Ltd., Surrey, UK) equipped with Texture Exponent Lite software for Windows. A compression cycle was performed at a constant speed of $0.5 \mathrm{mms}^{-1}$ to a depth of $8 \mathrm{~mm}$ of the sample, followed by a return to the original 
position. The force-time curve was obtained, and was used for the determination of firmness (the maximum force observed before the fracture). The stability of the gels was determined at $4{ }^{\circ} \mathrm{C}$ by measuring the syneresis for $96 \mathrm{~h} \mathrm{[10]}$.

\subsection{Statistical Analysis}

All measurements were in triplicate. Data were analyzed using XLSTAT software (V2008.1.50162). Linear correlations between any two samples were estimated by Pearson correlation analysis. Principal component analysis (PCA) was carried out to reduce the dimensions of variables and to visualize the similarities among different samples.

\section{Results and Discussion}

\subsection{Raw Materials}

The nine races of corn planted were identified as Capia, Culli, Morocho, Garrapata, Perlita, Brown Capia, Red, Crystalline Yellow and Cuzco (Figure 1). For the identification of the different breeds, the manuals provided by the germplasm bank INTA-Pergamino were used.

\subsection{Chemical Composition, Amylose Percentage and Endosperm Hardness}

Table 2 presents the chemical composition and hardness of the endosperms of the different races. According to the endosperm hardness, the races were ordered from the hardest to the softest, as follows: Perlita, Morocho, Rojo, Cristalino amarillo, Culli, Capiamarrón, Capia, Garrapata and Cuzo. The moisture varied between $9.01 \%$ and $10 \%$. The protein content varied between $7 \%$ and $12 \%$. The Morocho and Capia Marron breeds had the highest and lowest protein contents, respectively. Culli and Perlita maize had the lowest (3.8\%) and highest (5.7\%) lipid content respectively. No correlation was observed between the hardness of the endosperm and the protein or ash content. However, a positive correlation was observed between lipid content and hectolitre weight. The amylose content varied between 15 and $29 \mathrm{mg} / 100 \mathrm{~g}$. A tendency to increase the content of amylose was observed with the increase in hardness of the endosperm [11].

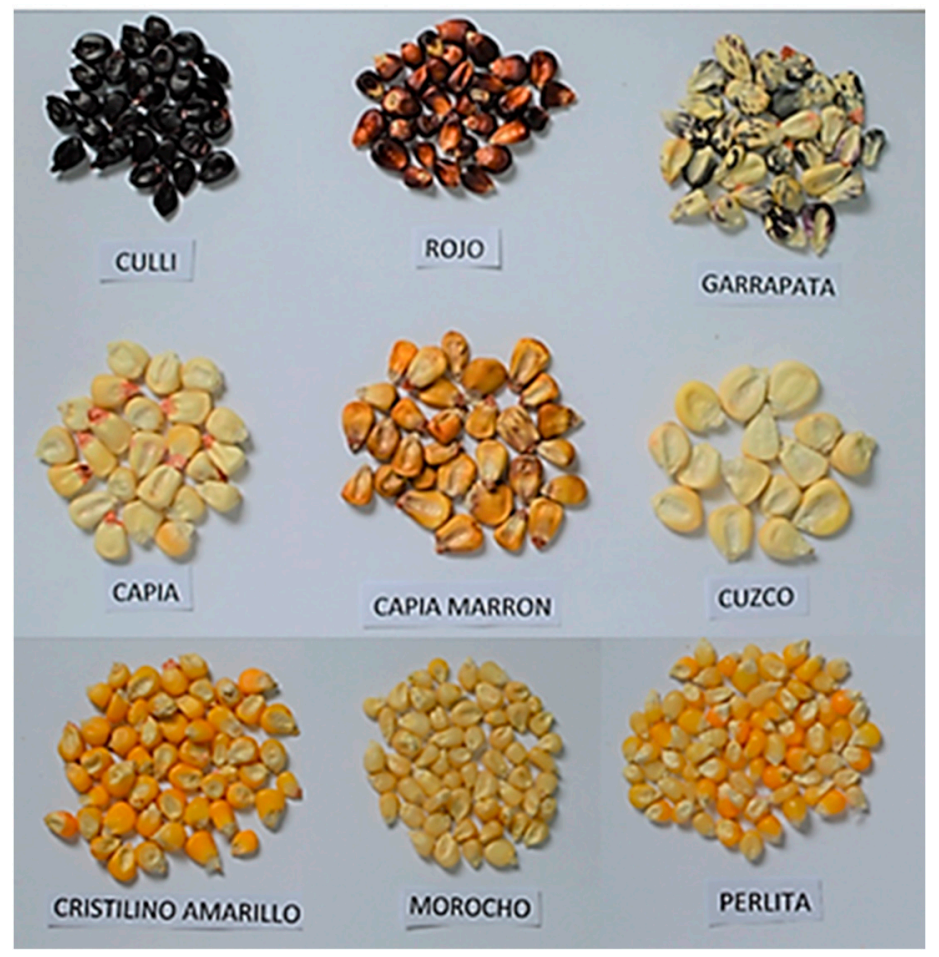

Figure 1. Races identified during the harvest. 


\subsection{Technological and Thermal Properties of Whole Meal Flours}

The values of WHC were between 2.3 at $30{ }^{\circ} \mathrm{C}$ and 3.6 at $70{ }^{\circ} \mathrm{C}$ (Table 2). The Perlita race showed the lowest values, which could be attributed to the low fiber, starch and protein contents. WHC values, in general, increased at $70{ }^{\circ} \mathrm{C}$ due to the swelling of the starch associated with the gelatinization process. The Perlita race had the lowest $\mathrm{OHC}$, which was significantly different from the rest of the samples, possibly due to the higher lipid content and lower protein content [12]. The peak gelatinization temperature for the different corn races varied between 67 and $69^{\circ} \mathrm{C}$. There were no significant differences in enthalpy of gelatinization between the starches of the different maize races, indicating that similar energies are required for gelatinization. The temperature range of gelatinization $(\Delta \mathrm{T})$ varied between $13{ }^{\circ} \mathrm{C}(\mathrm{Cuzco})$ and $25^{\circ} \mathrm{C}(\mathrm{Culli})$, which suggests a wide diversity in gelatinization properties. The wholemeal flours are a very complex matrix; the presence of proteins and fibers hinders the access to water of the starch, increasing the Tf and $\Delta \mathrm{T}$. The gels presented a wide variation in firmness $(16-81 \mathrm{Kp})$, and the lowest firmness corresponds to the gels of Cuzco (very soft endosperm) and the greatest to the Perlita (hard endosperm). However, no correlation was observed with endosperm hardness. The stability of the gels over $96 \mathrm{~h}$ in refrigeration was represented by syneresis between $4 \%$ and $32 \%$; the greater stability was found for the Culli, and the least for Capia Marron. The percentage of syneresis correlated positively with the amylose content.

\subsection{Principal Component Analysis (PCA)}

Figure 2a shows the PCA applied to the chemical composition and techno-functional properties. The F1 factor explains $28.3 \%$ of the variability of the chemical composition, attributed mainly to the contents of ash and lipids, while F2 (21.09\%) is attributed to the amylose content. The sample with the highest positive F1 score was the Culli race, and the highest F2 was Perlita. The main techno-functional properties that contributed to F1 were WHC and firmness. In F2, the variability was contributed by the $\mathrm{OHC}$ and syneresis. Only the variable $\Delta \mathrm{H}$ is close to the crossing of the axes, which suggests its low contributions to the variability of the properties. It corresponds for F1 to the race Culli, and for F2 to Perlita. In Figure 2b, two groups of races with similar characteristics are distinguished: one composed of the Capia, Cuzco and Rojo races, with high endosperm hardness and protein content; and the other composed of the Perlita, Cristalino Amarillo and Morocho races, which formed firm gels. The Capia Marron and Culli breeds showed distance from the other two groups, suggesting that their properties are unique. 


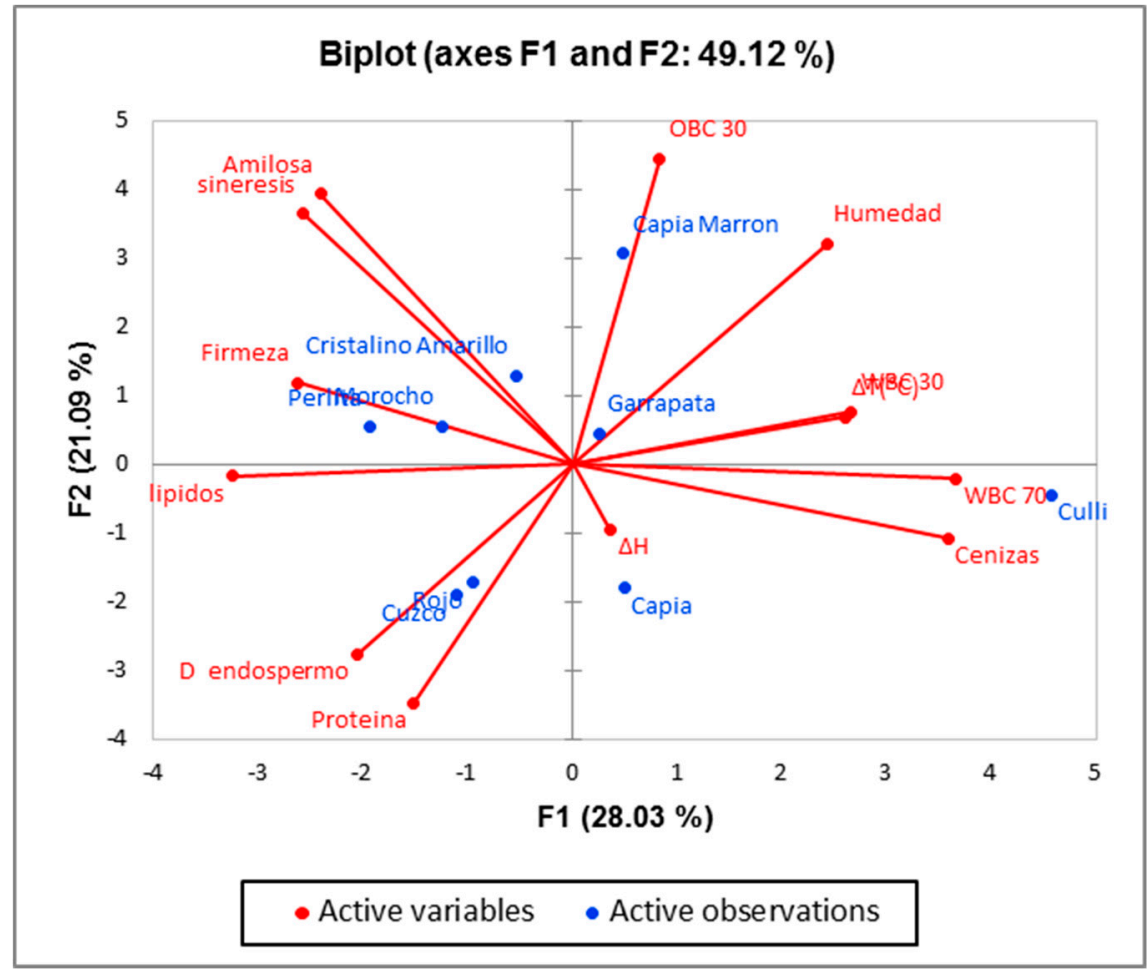

(a)

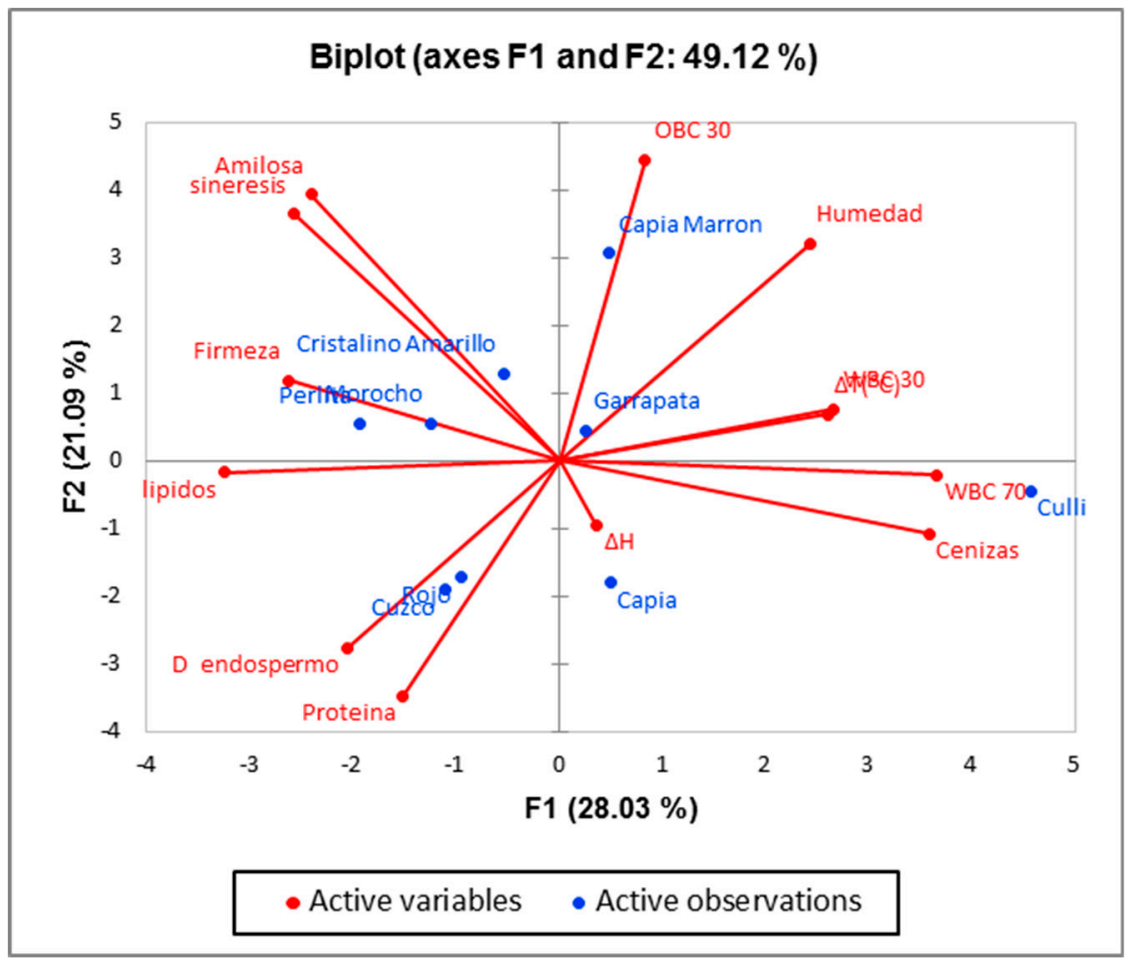

(b)

Figure 2. PCA of properties of maize races; (a) Chemical composition and techno-functional properties; (b) Grouping of maize races. 
Table 2. Physicochemical and techno-functional properties of Andean corns.

\begin{tabular}{|c|c|c|c|c|c|c|c|c|c|c|c|c|c|c|}
\hline Razas & Moisture & Proteín & Lípids & Ash & Amilylose & WHC $30^{\circ} \mathrm{C}$ & $\begin{array}{l}\text { WHC } \\
70^{\circ} \mathrm{C}\end{array}$ & $\begin{array}{l}\mathrm{OHC} \\
30^{\circ} \mathrm{C}\end{array}$ & $\begin{array}{c}\text { Firmeza } \\
\mathrm{Kp}\end{array}$ & $\begin{array}{c}\mathrm{S} \\
(\%)\end{array}$ & Hardness & $\begin{array}{c}\mathrm{T}_{\mathrm{p}} \\
\left({ }^{\circ} \mathrm{C}\right)\end{array}$ & $\begin{array}{c}\Delta \mathrm{T} \\
\left({ }^{\circ} \mathrm{C}\right)\end{array}$ & $\begin{array}{l}\Delta \mathbf{H} \\
\mathrm{J} / \mathrm{g}\end{array}$ \\
\hline Capia Marron & $9.78^{c}$ & $7.04^{\mathrm{a}}$ & $4.20^{\mathrm{c}}$ & $1.31^{\mathrm{d}}$ & $29.81^{\mathrm{f}}$ & $3.43^{c, d}$ & $6.83^{b}$ & $3.37^{\mathrm{c}}$ & $23.48^{b, c}$ & $32.00^{f}$ & $61.94^{d}$ & $68.55^{c}$ & $18.70^{b}$ & $9.27^{c}$ \\
\hline Cristalino Amarillo & $9.88^{\mathrm{d}, \mathrm{e}}$ & $11.28^{c, d}$ & $4.31 \mathrm{c}, \mathrm{d}$ & $1.23^{c}$ & $26.08^{c, d}$ & $3.19^{b}$ & $6.51^{a}$ & $3.26^{b, c}$ & $37.30^{\mathrm{d}}$ & 29.65 e,f & $73.07 .09^{\mathrm{f}}$ & $67.62^{c, d}$ & $18.32^{b}$ & $9.31^{\mathrm{c}}$ \\
\hline Perlita & $9.93^{\text {e }}$ & $9.49^{b}$ & $6.14^{\mathrm{g}}$ & $1.17^{\mathrm{b}}$ & $28.43^{\mathrm{d}, \mathrm{e}}$ & $2.31^{a}$ & $7.41^{\mathrm{c}}$ & $2.87^{a}$ & $81.20^{f}$ & $19.99^{c}$ & $80.94^{j}$ & $61.89^{b}$ & $20.38^{c}$ & $9.01^{c}$ \\
\hline Cuzco & $9.35^{b}$ & $11.08^{c}$ & $4.00^{\mathrm{b}}$ & $1.18^{b}$ & $23.68^{b, c}$ & $2.37^{a}$ & $6.89^{b}$ & $2.87^{a}$ & $16.04^{a}$ & $11.68^{b}$ & $55.03^{a}$ & $65.96^{b, c}$ & $13.26^{\mathrm{a}}$ & $9.57^{c}$ \\
\hline Garrapata & $9.79 \mathrm{c}, \mathrm{d}$ & $10.87^{c}$ & $4.41 \mathrm{~d}, \mathrm{e}$ & $1.35^{\mathrm{d}}$ & $25.31^{c}$ & $3.59 \mathrm{~d}$ & $7.85^{\mathrm{d}}$ & $3.15^{a, b, c}$ & 17.87 a,b & $26.44^{\mathrm{d}, \mathrm{e}}$ & $57.99 \mathrm{~b}$ & $63.34 \mathrm{c,d}$ & $16.9 \mathrm{~b}$ & $7.820^{a}$ \\
\hline Capia & $9.29 \mathrm{~b}$ & $10.98^{c}$ & $4.48^{\mathrm{d}, \mathrm{e}}$ & $1.67^{\mathrm{f}}$ & $21.68^{b}$ & $3.36 b^{c}$ & $7.03^{b}$ & $3.01^{a, b}$ & $29.38^{b, c}$ & $11.68^{b}$ & $64.03^{d}$ & $69.28^{d}$ & $18.34^{b}$ & $8.97^{b}$ \\
\hline Morocho & $9.74^{\mathrm{c}}$ & 11.99 e & $4.55^{\mathrm{e}}$ & $1.13^{a}$ & $28.74 \mathrm{~d}, \mathrm{e}$ & $3.35 b^{c}$ & $7.36^{c}$ & $3.22 b, c$ & 59.95 e & $27.20 \mathrm{~d}, \mathrm{e}$ & $78.45^{\mathrm{h}}$ & $61.59 a$ & $20.55^{c}$ & $9.17 \mathrm{c}$ \\
\hline Rojo & $9.08^{a}$ & $11.70^{\mathrm{d}, \mathrm{e}}$ & $5.33^{f}$ & $1.15^{\mathrm{a}, \mathrm{b}}$ & $15.82^{a}$ & $3.58^{\mathrm{d}}$ & $6.57^{a}$ & $2.94^{a, b}$ & $29.12^{c}$ & $25.60^{d}$ & $73.52 \mathrm{~g}$ & $61.84^{a, b}$ & $20.81^{c}$ & $9.45^{c}$ \\
\hline Culli & $10.29^{\mathrm{f}}$ & $9.64^{b}$ & $3.54^{\mathrm{a}}$ & $1.57^{\mathrm{e}}$ & $16.57^{a}$ & $3.62^{d}$ & $9.19^{\mathrm{d}}$ & $3.05^{a, b, c}$ & $18.11^{a, b}$ & $4.13^{\mathrm{a}}$ & $66.09 \mathrm{e}$ & $60.54^{a}$ & $24.91^{\mathrm{d}}$ & $9.49^{c}$ \\
\hline
\end{tabular}

WHC: Water holding capacity; OHC: Oil holding capacity; S: Percentage of syneresis; Tp: Peak temperature; and $\Delta H$ : enthalpy (Joule/g batter). Different letters in the same column mean significantly different $(p<0.05)$. 


\subsection{Principal Component Analysis (PCA)}

Figure 2a shows the PCA applied to the chemical composition and techno-functional properties. The F1 factor explains $28.3 \%$ of the variability of the chemical compositions, attributed mainly to the contents of ash and lipids, while F2 (21.09\%) is attributed to the amylose content. The samples with the highest positive F1 score correspond to the Culli race, and the highest F2 to Perlita. The main techno-functional properties that contribute to F1 are WHC and firmness. In F2, the variability was contributed by the $\mathrm{OHC}$ and syneresis. Only the variable $\Delta \mathrm{H}$ is close to the crossing of the axes, which suggests its minimal contribution to the variability of the properties. It corresponds for F1 to the race Culli, and for F2 to Perlita. In Figure 2b, two groups of races with similar characteristics are distinguished: one composed of the Capia, Cuzco and Rojo races, with high endosperm hardness and protein content; and the other composed of the Perlita, Cristalino Amarillo and Morocho races, which formed firm gels. The Capia Marron and Culli breeds showed distance from the other two groups, suggesting that their properties are unique.

\section{Conclusions}

A great variability in the chemical composition and technical-functional properties has been observed among the nine integral flours of the Andean corn races. According to their broad techno-functional behaviors, they could be used in different technological processes to produce integral foods. The analysis of the main components revealed that Culli and Capia Marron differ from the other races, mainly due to the formation of gels of intermediate hardness, and the high stability of Culli. The recovery of these races through the revaluation of their technological properties will contribute to the maintenance of biodiversity and the food security of rural families in the Andean region of Jujuy, Argentina.

Acknowledgments: This work was supported by grant Ia ValSe-Food-CYTED (Ref. 119RT0567) and Consejo Nacional de Investigaciones Científicas y Técnicas (CONICET) and Secretaría de Ciencia y Técnica y Estudios Regionales (SECTER), Universidad Nacional de Jujuy (Argentina).

\section{References}

1. Ramos, R.S.; Hilgert, N.I.; Lambaré, D.A. Agricultura Tradicional y riqueza de maíces (Zea mays). Estudio de Caso en Caspalá, provincia de Jujuy, Argentina. Bol. Soc. Argent. Bot. 2013, 48, 607-621.

2. Hung, P.V.; Maeda, T.; Morita, N. Waxy and high-amylose wheat starches and flours-Characteristics, functionality and application. Trends Food Sci. Technol. 2006, 17, 448-456, doi:10.1016/j.tifs.2005.12.006.

3. Salinas-Moreno, Y.; Aguilar-Modesto, L. Effect of maize (Zea mays L.) grain hardness on yield and quality of tortilla. Ing. Agric. Y Biosist. 2010, 2, 5-11, doi:10.5154/r.inagbi.2010.08.009.

4. Wolf, B. Polysaccharide functionally through extrusion processing. Curr. Opin. Colloid Interface Sci. 2010, 15, 50-54, doi:10.1016/j.cocis.2009.11.011.

5. Morita, N.; Maeda, T.; Miyazaki, M.; Yamamori, M.; Miura, H.; Ohtsuka, I. Effect of substitution of waxy-wheat flour for common flour on dough and baking properties. Food Sci. Technol. Res. 2002, 8, 119124, doi:10.3136/fstr.8.119.

6. Gimenez, A.; Drago, S.; De Gree, F.D.; Gonzalez, R.; Lobo, M.; Samman, N. Rheological, functional and nutritional properties of wheat/broad bean (Vicia faba) flour blend for pasta formulation. Food Chem. 2012, 134, 200-206, doi:10.1016/j.foodchem.2012.02.093.

7. Saldaña, E.; Rios-Mera, J.; Arteaga, H.; Saldaña, J.; Samán, C.M.; Selani, M.M.; Villanueva, N.D.M. How does starch affect the sensory characteristics of mazamorra morada? A study with a dessert widely consumed by Peruvians. Int. J. Gastron. Food Sci. 2018, 12, 22-30, doi:10.1016/j.ijgfs.2018.01.002.

8. AOAC. Official Methods of Analysis, 16th ed.; Association of Official Analytical Chemists: Washington, DC, USA, 1995.

9. Juliano, B.; Perez, C.; Blakeney, A.; Castillot, D.; Kongseree, N., Laingnelet, B.; Lapis, E.; Murty, V.; Webb, B. International cooperative testing on the amylose content of milled rice. Starch/Staerke. 1981, 33, 157-162, doi:10.1002/star.19810330504. 
10. Eliasson, A.C.; Kim, H.R.; Changes in rheological properties of hydroxypropyl potato starch pastes during freeze-thaw treatments. I. A rheological approach for evaluation of freeze-thaw stability. J. Texture Stud. 1992, 23, 279-295, doi:10.1111/j.1745-4603.1992.tb00526.x.

11. Robutti, J.L.; Borras, F.S.; González, R.J.; Torres, R.L.; De Greef, D.M. Endosperm properties and extrusion cooking behavior of maize cultivars. Food Sci. Technol. 2002, 35, 663-669, doi:10.1006/fstl.2002.0926.

12. Ahmed, J.; Al-Attar, H.; Arfat, Y.A. Effect of particle size on compositional, functional, pasting and rheological properties of commercial water chestnut flour. Food Hydrocoll. 2016, 52, 888-895, doi:10.1016/j.foodhyd.2015.08.028.

(C) 2020 by the authors. Licensee MDPI, Basel, Switzerland. This article is an open access article distributed under the terms and conditions of the Creative Commons Attribution (CC BY) license (http://creativecommons.org/licenses/by/4.0/). 